УДК 94(5)

\title{
К ВОПРОСУ ОБ ИЗУЧЕНИИ ИСТОРИИ ВЕЛИКОГО ШЕЛКОВОГО ПУТИ (ОБОБЩАЯ ОПЫТ ОТДЕЛЬНЫХ ИССЛЕДОВАТЕЛЕЙ)
}

Тематика Великого Шелкового пути (ВШП) становится популярной в России с начала 1990-х гг., когда в результате политических перемен страна стала более открытой внешнему миру. Ученые России и других стран проявили большое внимание к историческому опыту ВШП в связи с тем, что он дает уникальную возможность проследить трансрегиональные интеграционные связи внутри Евразии на протяжении последних двух тысяч лет. В вузах Северного Кавказа интерес к теме ВШП закономерен, так как один из участков Шелкового пути проходил именно здесь. Опыт изучения истории ВШП рассматривается в осуществляемых учеными Центра и Северо-Кавказского региона совместными проектами, в рамках которых в вузах региона проводятся научные конференции, защищаются диссертации, читаются дисциплины по выбору. Заметными форумами, на которых были представлены проблемы изучения связей между народами Северной Евразии, являются в недавнем прошлом межрегиональная научная конференция «Минаевские чтения», проходившая на историческом факультете Ставропольского государственного университета, а ныне представительная международная научно-практическая конференция «Историко-культурное наследие Великого шелкового пути и продвижение туристских дестинаций на Северном Кавказе», проводимая в СКФУ. Репрезентативным примером исследования, которое поднимает вопросы внутриевразийской коммуникации еще в древности является кандидатская диссертация представительницы Южной Кореи Ли Джи Ын, защищенная в Ставропольском госуниверситете и посвященная теме контактов ранних кочевников южнорусских степей с китайской цивилизацией, в которой автором изучаются китайские импорты и подражания им в памятниках между Южным Уралом и Балканами. В вузах Северного Кавказа имеется опыт разработок периодизаций всемирной истории, в которых ВШП выступает, как важная артерия, способствовавшая интеграции весьма удаленных друг от друга народов во всемирно-исторический процесс, в древности и средневековье (исторический факультет АГПУ). Вузы Северного Кавказа вносят свой вклад в развитие проблем исследования ВШП, что имеет сегодня большое прикладное значение в связи с развитием международного партнерства и туризма.

Ключевые слова: Великий Шелковый путь (ВШП) евразийская интеграция, Ханьский Китай, историография Великого шелкового пути, интеллектуальная история.

\section{S. Dudarev}

\section{ON STUDYING THE HISTORY OF THE GREAT SILK ROAD (REVIEW OF DIFFERENT STUDIES)}

The theme of the Great Silk Road (GSR) has become popular in Russia since the early 1990s, when, as a result of political changes, the country became more open to the outside world. Scientists of Russia and other countries have shown great attention to the historical experience of the GSR due to the fact that it provides a unique opportunity to trace the trans-regional integration ties within Eurasia over the past two thousand years. In the universities of the North Caucasus, interest in the topic of GSR is logical, since one of the sections of the Silk Road was held here. The experience of studying the history of high school education is examined in joint projects carried out by scientists of the Central and the North Caucasus region, within the framework of which scientific conferences are held at universities, dissertations are defended, elective disciplines are read. Significant forums in which the problems of studying relations between the peoples of Northern Eurasia were presented at the interregional scientific conference "The Minayev Readings" held at the history department of Stavropol State University, and now the representative international scientific and practical conference "The Historical and Cultural Heritage of the Great Silk Road and promotion of tourist destinations in the North Caucasus", held in the North Caucasus Federal University. A representative example of a study that raises issues of intra-Eurasian communication back in antiquity is the Ph.D. thesis of the South Korean representative Lee Ji Eun, defended at the Stavropol State University and devoted to the topic of contacts between the early nomads of the South Russian steppes with Chinese civilization, in which the author studies Chinese imports and imitations of monuments between them South Ural and the Balkans. In the universities of the North Caucasus, there is experience in the development of periodizations of world history, in which the GSR acts as an important artery that promoted the integration of very distant peoples into the world-historical process, in antiquity and the Middle Ages (the history department of the Armavir State Pedagogical University). The universities of the North Caucasus contribute to the development of the problems of the GSR, which is of great practical importance today in connection with the development of international partnership and tourism.

Key words: Great Silk Road, Eurasian integration, Han China, historiography of Great Silk Road, intellectual history. 
Еще в 1990-е гг. отечественными специалистами, т.е. Российским фондом культуры и Центром «Шелковый путь», который имел свое региональное подразделение на Ставрополье, совместно с зарубежными коллегами осуществлялся крупный научный проект, предполагавший изучение стран лежавших на этой трассе. В рамках данного проекта проводились научные конференции [35] и печатались сборники трудов [8]. Тематика Великого Шелкового пути (ВШП) рассматривалась и на проводившейся ряд лет в Ставропольском государственном университете (ныне Северо-Кавказский федеральный университет) силами исторического фракультета (профф. А. А. Кудрявцев) региональной научно-практической конференции «Минаевские чтения», ставшей заметным явлением в научной жизни северокавказских вузов и научно-исследовательских институтов. Проблемы ВШП получили свое отражение в интеграционной периодизации, предложенной кафедрой всеобщей истории Армавирского государственного педагогического института (ныне - университета) в первой половине 1990-х гг. [9, с. 126-135]. На диссертационном Совете при Ставропольском государственном университете в 2000-е гг защищались диссертации, содержание которых напрямую касалось изучения проблем ВШП [33] Сегодня традиции, заложенные в 1990-2000-е гг. получают свое полезное, зримое и весомое продолжение в СКФУ в рамках представительной международной научно-практической конференции «Историко-культурное наследие Великого шелкового пути и продвижение туристских дестинаций на Северном Кавказе», регулярно проводимой ныне в СКФУ [39]. Иными словами, тематика ВШП по-прежнему имеет высокую научную актуальность. Она должна рассматриваться в контексте проблематики взаимоотношений центров высокой цивилизации и т.н. варварской периферии выяснения степени и характера влияния классовых обществ на социо-политические, культурные и иные, в том числе, интеграционные, процессы в племенной среде. Несомненна связь указанной проблематики с темой (приобретающей в наше время все большее звучание) трансрегиональных связей между Западом и Востоком, которая особенно актульна в контексте глобализации.

Обратимся к кандидатской диссертации представительницы Южной Кореи г-жи Ли Джи Ын, обойденной вниманием специалистов по ВШП [33]. Автор обращает исследователей к теме контактов ранних кочевников южнорусских степей с китайской цивилизацией, для чего он прибег к изучению китайских импортов и подражаний ему в памятниках между Южным Уралом и Балканами.

Ли Джи Ын представила репрезентативную экспозицию письменных источников, как восточных, так и западных, в контексте которых рассматриваются приводимые в работе археологические артефракты. Автор дает обзор таких важнейших китайских письменных источников, как «Исторические записки» («Шизцы») Сымя Цяня, “Ханьская история» («Ханьшу») Бань Гу и «Позднеханьская история» ("Хоуханьшу») Фань Ё. В них имеются сведения о народах Евразии, интересовавших китайцев в качестве исторических партнеров и, одновременно, объектов экспансии, описываются события этнополитической истории периода Хань, которые были связаны с отношениями китайской империи и племен Западного края. Сочинения Гекатея, Геродота, Страбона, Гая Плиния Секунда Старшего, Клавдия Птолемея и др. представляют в исследовании античные источники Их содержание указывает на существовавший в греко-римском мире стабильный интерес к Востоку. Примечательно, что китайские письменные источники создавались с целью передачи сведений потомкам, а западные были адресованы современникам как справочники и путеводители.

В разделе «Этнополитическая ситуация в евразийских степях в последние века до нашей эры первые века нашей эры» автором представлена емкая картина формирования племенных союзов сюнну, усуней, юэчжи и др. и их постоянной и ожесточенной борьбы между собой, которая шла в тесном взаимодействии с китайской цивилизацией и экспансией Хань на запад. Она отражает драматичное и одновременно плодотворное столкновение двух миров - кочевого и оседлого, противоборства китайского цивилизационного центра с кочевой периферией. Работа, проделанная автором, служит основой для понимания ритмов взаимоотношений ханьского Китая с варварской средой, локализовавшейся к западу от него, и динамики распространения китайских импортов у населения евразийского ареала.

Третья глава работы посвящена детальному исследованию и систематизированию тщательного собранного фонда китайских импортов из археологических объектов Юга России: практически всех известных на начало XXI в. находок ханьских зеркал и подражаний им, нефритовых деталей мечей, и мечей с так называемым ромбовидным перекрестием. Автор весьма разносторонне анализирует типы китайских зеркал с изучаемой территории, используя свое знание китайского языка, выясняет прочтение сделанных на них надписей, устанавливает семантику данных предметов.

Данные эпиграффики позволяют более четко структурировать зеркала на ряд хронологических групп (всего 6). Особенности нанесения иероглифов на зеркала дают возможность автору установить их китайский или местный генезис. Исследователь тонко демонстрирует отличия иероглифических знаков, нанесенных китайскими мастерами, от тех, которые были изготовлены автохтонами Юга Восточной Европы в подражание ханьским не совсем умело: каллиграфия в Китае всегда была высоким искусством. Китайские зеркала и мечи, найденные на Юге России, рассматриваются специалистом на обширном фоне китайских и иных восточноазиатских параллелей, что придает убедительность его выводам, одновременно показывая эрудицию автора. Правда, не со всеми его выводами в этом отношении можно согласиться. Например, он относит к влияниям 
эпохи Хань все длинные мечи без металлических наверший и перекрестий, обнаруженные в памятниках Юга России. Подобное оружие хорошо известно в Восточной Европе и на Кавказе в эпоху поздней бронзы [55, taf. 12, 17], киммерийское [8], и скифо-сарматское время [16, с. 72-78; 33] как среди кочевников, так и оседлых племен. Материалы Северного Кавказа, относящиеся не только к древности, но более поздним временам [43], указывают на то, что для местного рубящего оружия наличие перекрестий не является обязательным.

В главе «Причины проникновения китайского импорта за пределы империи Хань» Ли Джи Ын верно определяет причины, приведшие к появлению ханьских предметов на территории «варварской периферии» и в том числе, на юге современной России. Таковы: переселение и бегство населения империи за пределы Хань, военные трофеи, китайские военные поселения, подарки иноземным вождям, ограбление послов (и купцов - С.Д.), транзитная и приграничная торговля, функционирование Великого Шелкового пути, миграции кочевников в Восточную Европу. Специалист дифференцирует эти причин в зависимости от того, насколько тот или иной район был более близок или удален от самого Китая.

Одновременно мы считаем необходимым уточнить причины появления китайского импорта у населения Евразии. Автор приводит, например, вполне справедливое положение А. М. Хазанова о том, что дань и подарки кочевникам производились с целью откупиться от их набегов. Рассуждая о начале функционирования Шелкового пути, Ли Джи Ын верно приводит мысль о том, что на первом своем участке эта трасса не была собственно торговой артерией. По мнению Э. де ля Вессьера, торговля не являлась целью Китая. Вероятно, автор прав, утверждая, что движение китайских вещей происходило, главным образом, в политико-дипломатических и престижных целях. Но объяснение причин поступления китайских вещей к «варварам» требует ныне более углубленной трактовки. В случае с Ханьским Китаем дань тем или иным субъектам Западного Края нужно расценивать не только, а иногда и не столько как стремление купить себе мир ценой подношений. Отечественные ученые отмечают, что города Западного Края, под которым ими понимается Восточный Туркестан, отказывались от «даров Сына Неба». Они расценивали таковые как попытку вмешательства в свои внутренние дела [13]. Этот ракурс зазвучит еще более любопытно, если взять более поздний период отношений Китая с миром евразийских степей. Шедшие туда из Поднебесной предметы роскоши вызывали к себе двоякое отношение. Это чуждое богатство одновременно притягивало и отталкивало средневековых кочевников, которые связывали его $c$ соблазном и упадком нравов [8, с. 153]. Вряд ли случайно, что в более отдаленном будущем люди Востока, которые прекрасно осознавали, какую опасность несут внешние инновации для сохранения идентичности, используя, все же, таковые, стремились при этом к установлению приоритета своих ценностей (японский принцип вакон ёсай: «японский дух, западная техника», корейский «дондо саги», означающий по сути, то же самое).

В другом месте IV главы автор отмечает, что все иностранные гости, прибывавшие ко Двору (в том числе послы и заложники), приносили, как правило, подарки. Подчеркнем, что с точки зрения китайского менталитета, это были не подарки, а дань. Именно в такой форме мог происходить обмен «варваров» с Тяньцзы, «Сыном Неба», владыкой Срединной империи. Причем в обмен на эту дань Китай должен был дать больше. Этого требовал его неизмеримо более высокий престиж [6, с. 382].

Исследуя причины появления китайского импорта в Восточной Европе, Ли Джи Ын делает вывод, что в основе этого факта лежит аланская миграция, произошедшая между 65-49 гг. до н.э. (или несколько позже). Подтверждением этого, по мнению автора, является хронология ханьских зеркал. С этим мы отчасти согласны. Однако сам же исследователь сообщает о более сложной хронологической структуре китайского импорта с юга России. Одна группа памятников с ханьскими зеркалами датируется І-началом || вв. Н.э. а другая группа с ханьскими зеркалами - концом II - началом III в. н.э. Памятники с нефритовыми деталями мечей относятся к позднесарматскому времени, т.е. II - III вв. Н.э. В принципе, связь движения китайских вещей исследуемого времени с известной аланской миграцией возможна. Тем не менее, нужно учитывать и фактор трансрегиональных торгово-обменных связей, в том числе и по Великому Шелковому пути.

Таким образом, работа Ли Джы Ын дает хорошее представление о тех сложных, многообразных исторических процессах, в ходе которых возникла разветвленная, опосредованная система связей между народами и племенами Великой Степи и далеким Китаем в древности.

В русле проблем изучения ВШП большой интерес представляет исследование восприятия друг другом представителями различных культур Евразии, начиная с древности и заканчивая новым временем. В этом отношении, важную роль играет упоминавшаяся выше коллективная монографрия “Элита в истории древних и средневековых народов Евразии» [52]. Обратим особое внимание на некоторые положения главы $X$ «Кочевая элита степной империи. VI-IX вв.». В ней отмечено, в частности то, что религиозные системы добиваются гораздо более серьезных успехов и имеют бо̀льшую эффективность, когда им удается адаптироваться к мировоззрению данной «атакуемой» аудитории, создавая ощущение, что «новое» послание на самом деле является лишь “улучшением» старой веры и полностью соответствует традиционным представлениям людей [52, c. 163]. Религией, которая предъявляла в первые века своего существования менее всего требований к кочевникам Центральной Азии, был ислам. Мусульманское духовенство требовало от кочев- 
ников единственно официально принять эту религию и декларировать свою веру в Аллаха [52 c. 164]. Похожая ситуация существовала до конца XVIII - середины XIX в. на Северном Кавказе Представители целого ряда народов Северного Кавказа, официиально принявшие в это время ислам, не придерживались строго догматической версии мусульманской религии. В их верованиях (особенно, у адыгов Закубанья) было немало элементов домонотеистических воззрений, а также христианства, олицетворявших синкретические представления местного северокавказского населения, что позволяет их аттестовать, как ересь [15]. Однако с конца XVIII в. наблюдается тенденция к радикализации ислама. Причиной для этого, по большому счету, не было желание властей массово христианизовать горцев, хотя проекты, направленные на христианизацию, как известно имели место. Так, известна своей деятельностью Осетинская духовная комиссия, действовавшая в XVIII в., и продолжившая затем работу в XIX в. [13, с. 104-112]. Большую известность получило «Общество восстановления православного христианства на Кавказе», учрежденное в январе 1860 г. по инициативе тогдашнего кавказского наместника А. И. Барятинского при поддержке представителей высших властей (великий князь Михаил Николаевич). Некоторые историки полагают, что деятельность «Общества» послужила одной из причин мухаджирства [37, с. 175]. Известны проекты отдельных, менее влиятельных лиц, направленные на христианизацию горев (А. А. Бегичев). Небудем забыватьиотом, чтосидеей проповедания Евангелия среди них вступал и А. С. Пушкин («Путешествие в Арзрум»). Впрочем, на наш взгляд, все эти проекты безнадежно запоздали, а если реализовывались, то фрагментарно и непоследовательно. Но главное, что даже после присоединения Крыма в 1783 г. говорить о христианизации было уже поздно - разразившееся в 1785 г. восстание шейха Мансура ярко свидетельствовало о том, что северокавказский ислам становится знаменем политической борьбы и этнической мобилизации против расширения присутствия России на Северном Кавказе.

На наш взгляд, обострение обстановки на Северном Кавказе в первой половине - середине XIX в. было прежде всего, связано не сколько с угрозой для горцев потери конфессиональной идентичности (несмотря на приведенные выше факты, целью российских властей в XVIII-XIX вв. по большому счету, никогда не была смена вероисповедания северокавказцев (о чем говорит например, опыт А. П. Ермолова) [47, с. 370-373] сколько с необходимостью отказа местного населения от распространенного среди них понимания свободы и принять российский уклад жизни с его бюрократией, муштрой и т.п. На Северном Кавказе имел место удивительный парадокс, отмеченный В. М. Батчаевым [47, с. 176]. Россия в результате «Кавказской войны» одержала политическую победу, а Османская империя - победила на «идеологическом фрронте». Большинство горских народов стали мусульманами и остаются ими по сей день. Вопрос - почему? И вновь можно обратиться к историческому опыту народов, живших на ВШП. Хотя кочевые народы воспринимали и чужое, но более всего они ценили свое [52, с. 55]. Именно ислам явился интегрирующим фактором, наиболее полно синтезировавшим ведущие ценности горских народов: приверженность традициям, маскулинность и связанная с ней система гендерных ролей, уважение к предкам и их опыту, устойчивость социальных структур, уходящих корнями в прошлое, и т.п. Сегодня мы видим, как все эти ценности явно доминируют в сознании северокавказцев. Впрочем, данное явление, именуемое футуро-архаикой, уже шагает и по миру.

Большое значение имеют международные научно-практические конференции, проведенные в г. Ставрополе на базе ФГАОУ ВО «Северо-Кавказский федеральный университет» в 2016 и 2017 гг. Два этих представительных фрорума имели общее название «Историко-культурное наследие Великого Шелкового пути и продвижение туристских дестинаций на Северном Кавказе». Наряду с проблемами туристских маршрутов, немало статей были посвящены различным странам и регионам в истории Великого шелкового пути.

Всем историкам, кто изучает Великий шелковый путь и преподает соответствующие данной проблематике курсы, было бы важно обратиться к опыту указанного фрорума, который важен, прежде всего, широким временным охватом археологического и исторического материала: от VI-IV тысячелетий до нашей эры вплоть до современности, когда актуальными становятся вопросы об использовании исторического наследия Великого шелкового пути. Столь же широк региональный аспект проблематики, связанной с функционированием Великого шелкового пути, охватывающий территории, начиная от Придонья, Северного Кавказа и Закавказья и заканчивая Китаем. Значительно разнообразие спектра исследовательских ракурсов, охватывающее проблемные поля истории, археологии, историографии, истории материальной и духовной культуры, экономики и туризма.

Прежде всего, следуя хронологическому принципу, следует отметить, что проблемы становления городов, возникающих на торговых магистралях древности, являются объектом исследования во многих опубликованных материалах. Проблемам античного и средневекового города посвящены статьи профессора А. А. Кудрявцева, доцента Е. А. Кудрявцева (Северо-Кавказский федеральный университет) о Дербенте в эпоху античности и средневековья и его значении в истории Великого шелкового пути [29; 30; 31]. Эти статьи основываются на богатом археологическом материале, накопленном авторами, который позволил отнести возникновение города к рубежу IV-III тыс. до н.э. и доказать, что уже с III в. до н.э. Дербентскиий проход имел торговые связи с эллинистическим миром Ближнего Востока, а в первые века 
нашей эры торговые контакты значительно активизировались. Дербент стал выступать важным центром международной торговли по кавказским маршрутам Великого шелкового пути, контролируя главные «ворота» Кавказа, через которые шел товарообмен между эллинистическими центрами Ближнего и Среднего Востока с античными городами Северного Причерноморья и Приазовья. Е. А. Кудрявцев, прослеживая значение Дербента в более поздний период (XI-XIII вв.), выделил три основных этапа развития международной торговли: XI-XIII вв. - период расцвета города как торгового центра; XIII-XVI вв. - резкое снижение торговли и экономический упадок Дербента из-за военно-политических потрясений; XVII-XVIII вB. новый подъем вследствие распространения российских и европейских товаров

Эти же проблемы рассматриваются В. П. Копыловым (Южный федеральный университет, г. Ростов-на-Дону), исследующим роль транзитной торговли в развитии урбанистических процессов в районе Нижнего Дона в VI-III вв. до н.э. региона Северного Причерноморья - на основе главным образом, полученных вследствие работы Южно-Донской экспедиции, археологических материалов [25]. Также имеет значение намерение автора соединить отдаленные эпохи во времени, судя по рекомендациям автора об организации в регионе археологического, историко-ландшафтного заповедника.

В статье Ш. Г. Кайтана (Абхазский институт гуманитарных исследований им. Д. Гулиа) речь идет о раннесредневековых крепостях Абхазии, игравших значительную роль на Западнокавказских ответвлениях Великого шелкового пути в IVVI вв. [20]. Статьи C. А. Сулеймановой (Институт востоковедения им. 3. М. Буниятова, Азербайджан) и А. Ю. Скакова (Институт востоковедения РАН) раскрывают значение кавказских маршрутов в сети древних торговых путей [46; 49]. C. С. Сулейманова привлекает сведения многих античных авторов, свидетельствующих о важной роли Кавказской Албании в образовании колоний и торговых путей древневосточных государств. А. Ю. Скаков уточняет места прохождения торговых коммуникаций через регион Кавказа, начиная с античности, и вплоть до 2015 г. Торгово-экономическим взаимоотношениям Южной Осетии со странами античного мира в Сармато-Аланский период посвящена статья Р. Х. Гаглоева (ЮгоОсетинский научно-исследовательский институт). В ней на основе археологических данных (главным образом, монет) рассматриваются межплеменные контакты, начиная с доскифских времен [10].

Общие проблемы торговых путей древности рассматриваются в статьях А. А. Туаллагова (Северо-Осетинский институт гуманитарных и социальных исследований им. В.И. Абаева), который отмечает, что интерес к ним возрос в ходе реализации международного проекта ЮНЕСКО «Комплексное исследование шелковых путей - путей диалога». На основе критического анализа античных текстов, автор стремится показать, что до се- редины І В. н. э. не имеется сведений о существовании северного торгового пути из Азии в Европу, как не было и самого пути [50]. Ю. А. Прокопенко (СКФУ, Ставрополь), сосредоточил внимание на цикличности функционирования транзитных путей на Северном Кавказе в $\mathrm{V}-\mathrm{XI}$ вв. в зависимости от международных отношений, вражды между великими державами и крупномасштабными войнами, чередующимися с относительно мирными и стабильными периодами, что свидетельствовало о «пульсирующем характере» действий магистралей. Автор выделяет чередование трех вариантов функционирования торговых путей, когда доминировали различные трассы [42]

Немало статей содержат проблемы, связанные с транзитом по Великому шелковому пути в период средневековья. Помимо вышеуказанных, следует отметить материал В. А. Бабенко (СКФУ) о торговых путях Центрального Предкавказья в эпоху Золотой Орды [1]. Исследователь по немногочисленным свидетельствам прослеживает торговые пути по территории Центрального Предкавказья, связывающие регион с Ираном, Нижним Подоньем и Китаем. Статья Н. Н. Гаруновой (Дагестанский государственный университет) посвящена индийским купцам, находящимся в составе астраханского и кизлярского купечества в XVII-XVIII вв. [11]., в ней затрагиваются противоречия и сложности взаимоотношений индийских купцов с русскими, которые, имея возможность вести полноценную торговлю только в своей стране, отстаивали свое превосходство на российском рынке

Помимо статей более традиционного плана, отразивших влияние Великого шелкового пути на историю многих народов в широком региональном аспекте на примерах Калмыкии [24], в Армении [27; 36], Средней Азии и Казахстана [40], горских поселений Северного Кавказа [12], имеются публикации, в которых основное внимание уделяется культурным контактам, осуществляемым в ходе функционирования Великого шелкового пути. В частности, Д. В. Пикалов писал о находках, относящихся к зороастрийским и манихейским верованиям на Северном Кавказе, на основе которых автор сделал вывод о притоке сюда мигрантов из Согдианы и Сасанидского Ирана, причем, не маргиналов, но лиц, способных основать святилища в крупных населенных центрах [38]. В статье А. А. Цуциева (Северо-Осетинский государственный университет им. К. Л. Хетагурова) говорится на основе археологического исследования могильников об артефактах культуры Востока в аланских памятниках Горной Осетии. В статье С. Б. Буркова (Институт истории и археологии, Владикавказ) и А. И Мальсагова (Ингушский государственный университет) характеризуются китайские бронзовые предметы, найденные в Ингушетии $[4 ; 48 ; 51]$

Материал теоретико-обобщающего и историографического характера содержится в ряде статей, посвященных теоретическим аспектам проблем, в частности, вопросу о наследии ци- 
вилизационных ценностей Великого шелкового пути. Среди немногих публикаций, в которых рассматриваются традиции Великого шелкового пути, следует выделить статьи И. В. Крючкова (СКФУ), которые посвящены осмыслению традиций и наследия экономических и культурных контактов «дороги шелка» в XIX - начале XX веков, когда активизировались связи России с Персией и Османской империей [27]. Анализируя статьи экспорта и импорта, динамику ввоза иностранного капитала, создание современной для того времени транспортной системы, автор приходит к выводу о положительном внешнеторговом сальдо региона, отмечает, что Кавказ в этот период стал активным субъектом мировых экономических связей, как и во времена Великого шелкового пути. Л. Н. Величко (СКФУ), анализирует развитие Программы европейской политики соседства на Южном Кавказе, неоднократно ссылаясь на опыт контактов Великого шелкового пути [7] В статье В. Н. Садченко (СКФУ), рассматривается экономический потенциал Великого шелкового пути и перспективы ЕАЭС [44]. И. А. Коробкина (СКФУ) раскрывает значение модели нового шелкового пути согласно современному китайскому проекту «Один пояс и один путь» [26]. Проблемы развития туризма на трассах Великого шелкового пути с учетом опыта прошлого рассматриваются в статье Л. П. Ермоленко (СКФУ) [17]. Традициям шелководства на Северном Кавказе посвящены материалы Н. Д. Судавцова (СКФУ), Т. В. Беликовой (СКФУ), которые отражают высокую степень актуальности и значимости этого товара на протяжении нескольких столетий $[47 ; 48]$.

Историографический ракурс выступает на первый план в статьях М. Е. Колесниковой (СКФУ) и А. Думикяна (Институт истории Национальной академии наук Армении) [16; 21; 22]. М. Е. Ко- лесникова анализирует труды, изданные в XX в. как отечественных историков-кавказоведов М. Г. Мошкова, С. Н. Савенко, Н. Е. Берлизова, А. С. Скрипкина, В. А. Кузнецова, А. А. Ерусалимской, И. В. Каминской, З. В. Доде, так и зарубежных, в которых ставятся и решаются вопросы, связанные с историей Великого шелкового пути В статье А. Думикяна исследуется значение армянского культурно-экономического фрактора в связи с историей Великого шелкового пути в трудах французских путешественников, начиная с XIII в. (Г Рубрук) и вплоть до XVII в. включительно.

Особо следует отметить участие зарубежных коллег в обсуждении проблем, связанных с историей Великого шелкового пути. Свои статьи предоставили Аттила Колонтари (доцент Капошварского университета, Венгрия): его работа посвящается историко-культурному наследию Юго-Западной Венгрии и перспективам развития туризма: особо выделяется значение города Печ, как важного торгового центра, а также мест, связанных с пребыванием здесь султана Сулеймана I, бальнеологических курортов, центров сельского туризма [23]. Профессор Ласло Чичман (декан факультета социальных наук и международных отношений Будапештского университета имени М. Корвина) опубликовал статью на английском языкe «The fault lines in the middle East after the military defeat of ISIS) (Линии разлома на Ближнем Востоке после военного поражения ИГИЛ) [54].

Обращение к материалам, опубликованным в вышеназванных трудах и сборниках, будет полезным для широкого круга исследователей и читателей, содержание указанных статей, научных монографий и диссертаций можно использовать в преподавании многих гуманитарных и прикладных дисциплин.

\section{Источники и литература}

1. Бабенко В. А. Торговые пути Центрального Предкавказья в эпоху Золотой Орды // Историко-культурное наследие Великого шелкового пути и продвижение туристских дестинаций на Северном Кавказе: материалы Международной научно-практической конференции (Ставрополь 28-29 сентября 2015 г.). Ставрополь: СКФУ, 2016. С. 87-91.

2. Батчаев В. М. Балкария в XV - начале XIX в. М.: Институт народов Кавказа, 2006. 239 с

3. Беликова Т. В. Петр I и идея перенесения восточной торговли шелком на территорию России // Историко-культурное наследие Великого шелкового пути и продвижение туристских дестинаций на Северном Кавказе: материаль III Международной научно-практической конференции (Ставрополь 5-7 октября 2017 г.). Ставрополь: СКФУ, 2017. C. $10-13$.

4. Бурков С. Б., Мальсагов А. И. Новые находки китайских бронз из Ингушетии // Историко-культурное наследие Великого шелкового пути и продвижение туристских дестинаций на Северном Кавказе: материалы Международной научно-практической конференции (Ставрополь 28-29 сентября 2015 г.). Ставрополь: СКФУ, 2016

5. Вардумян Г. Армения на Великом шелковом пути // Историко-культурное наследие Великого шелкового пути и продвижение туристских дестинаций на Северном Кавказе: материалы III Международной научно-практической конференции (Ставрополь, 5-7 октября 2017 г.). Ставрополь: СКФУ, 2017. Р. 13-17.

6. Васильев Л. С. История Востока. В 2 т. Т.1. М.: Высш. шк., 1994. 495 с.

7. Величко Л. Н. Эволюция программы европейской политики соседства на Южном Кавказе // Историко-культурное наследие Великого шелкового пути и продвижение туристских дестинаций на Северном Кавказе: материалы III Международной научно-практической конференции (Ставрополь 5-7 октября 2017 г.). Ставрополь: СКФУ, 2017. С. 21-25.

8. Вестник Шелкового пути. Археологические источники. Вып.1. М.: Шелковый путь, 1993. 340 с.

9. Виноградов В. Б., Дударев С. Л., Нарожный Е. И. Основные этапы всемирной истории. Методический материал // Восток. Азиатские общества: история и современность. 1995. №5. С. 126-135.

10. Гаглоев Р. X. Торгово-экономические взаимоотношения населения Южной Осетии с античным миром в Сарматско-Аланский период // Историко-культурное наследие Великого шелкового пути и продвижение туристских дестинаций на Северном Кавказе: материалы Международной научно-практической конференции (Ставрополь, 28-29 сентября 2015 г.). Ставрополь: СКФУ, 2016. С. 102-108. 
11. Гарунова Н. Н. Индийские купцы в составе астраханского и кизлярского купечества в XVII - середине XVIII вв. // Историко-культурное наследие Великого шелкового пути и продвижение туристских дестинаций на Северном Кавказе материалы Международной научно-практической конференции (Ставрополь, 28-29 сентября 2015 г.). Ставрополь СКФУ, 2016. С.161-164.

12. Дмитриев В. А. Традиционная горская экономика народов Северного Кавказа в контексте наследия Великого шелкового пути // Историко-культурное наследие Великого шелкового пути и продвижение туристских дестинаций на Северном Кавказе: материалы III Международной научно-практической конференции (Ставрополь, 5-7 октября 2017 г.) Ставрополь: СКФУ, 2017. С.28-32.

13. Дударев Д. С., Дударев С. Л. Северный Кавказ глазами представителей российского общества первой половины - середины XIX века. Армавир; Ставрополь: Дизайн-студия Б, 2017. 402 с.

14. Дударев С. Л. Взаимоотношения племен Северного Кавказа с кочевниками Юго-Восточной Европы в предскифскую эпоху. Армавир: Армавирское полиграф-предприятие, 1999. 400 с.

15. Дударев С. Л. О специфике исламизации Северо-Западного Кавказа в 1830 - начале 1860-х гг. // Материалы III Международного форума историков-кавказоведов «Русско-кавказские отношения: от первых контактов до современного единства) (17 ноября 2015 г., г. Ростов-на-Дону). Ростов-на-Дону: Изд-во Фонд науки и образования, 2015 C. $145-149$.

16. Думикян А. Армянский культурно-экономический фактор в освещении французской историографии в контексте шелкового пути. // Историко-культурное наследие Великого шелкового пути и продвижение туристских дестинаций на Северном Кавказе: материалы Международной научно-практической конференции (Ставрополь, 28-29 сентября 2015 г.). Ставрополь: СКФУ, 2016. С.114-118.

17. Ермоленко Л. П. проблемы и перспективы развития туристской отрасли на Северном Кавказе // Историко-культурное наследие Великого шелкового пути и продвижение туристских дестинаций на Северном Кавказе: материалы III Международной научно-практической конференции (Ставрополь, 5-7 октября 2017 г.). Ставрополь: СКФУ, 2017. C. $32-34$.

18. Историко-культурное наследие Великого шелкового пути и продвижение туристских дестинаций на Северном Кавказе: материалы III Международной научно-практической конференции (Ставрополь, 5-7 октября 2017 г.). Ставрополь: СКФУ, 2017. $288 \mathrm{c}$

19. История Востока в 6-ти Т. Т.1. Восток в древности. М.: Вост.лит., 1997. 688 с.

20. Кайтан Ш. Г. Раннесредневековые крепости Абхазии на Великом шелковом пути (проблемы выявления, учета и сохранения) // Историко-культурное наследие Великого шелкового пути и продвижение туристских дестинаций на Северном Кавказе: материалы Международной научно-практической конференции (Ставрополь, 28-29 сентября 2015 г.) Ставрополь: СКФУ, 2016. С .42-45.

21. Колесникова М. Е. Северокавказская трасса Великого шелкового пути: к историографии вопроса // Историко-культурное наследие Великого шелкового пути и продвижение туристских дестинаций на Северном Кавказе: материалы Международной научно-практической конференции (Ставрополь, 28-29 сентября 2015 г.). Ставрополь: СКФУ, 2016. С. $118-122$.

22. Колесникова М. Е. Следы Великого шелкового пути на Северном Кавказе: городище Маджары в исторических сочинениях XVIII века // Историко-культурное наследие Великого шелкового пути и продвижение туристских дестинаций на Северном Кавказе: материалы III Международной научно-практической конференции (Ставрополь, 5-7 октября 2017 г.). Ставрополь: СКФУ, 2017. С. 35-38.

23. Колонтари А. Историко-культурное наследие Юго-Западной Венгрии и перспективы развития туризма в регионе // Историко-культурное наследие Великого шелкового пути и продвижение туристских дестинаций на Северном Кавказе: материалы III Международной научно-практической конференции (Ставрополь, 5-7 октября 2017 г.). Ставрополь: СКФУ, 2017. С. 38-41.

24. Кольцов П. М. Кольцова К. П. великий шелковый путь на территории Калмыкии // Историко-культурное наследие Великого шелкового пути и продвижение туристских дестинаций на Северном Кавказе: материалы III Международной научно-практической конференции (Ставрополь, 5-7 октября 2017 г.). Ставрополь: СКФУ, 2017. С. 42-44.

25. Копылов В. П. Роль урбанистических центров Нижнедонского культурно-исторического района в транзитной торговле Востока и Запада (первая половина VI - первая половина III вВ. до н.э.) // Историко-культурное наследие Великого шелкового пути и продвижение туристских дестинаций на Северном Кавказе: материалы Международной научно-практической конференции (Ставрополь, 28-29 сентября 2015 г.). Ставрополь: СКФУ, 2016. С. 80-87.

26. Коробкина И. А. Новый шелковый путь: реализация концепции китайского проекта "Один пояс и один путь» // Историко-культурное наследие Великого шелкового пути и продвижение туристских дестинаций на Северном Кавказе: материалы III Международной научно-практической конференции (Ставрополь, 5-7 октября 2017 г.). Ставрополь: СКФУ, 2017. С. 44-46.

27. Крючков И. В. Кавказ в мировой экономической системе XIX - начала XX веков: продолжение традиций Великого шелкового пути // Историко-культурное наследие Великого шелкового пути и продвижение туристских дестинаций на Северном Кавказе: материалы Международной научно-практической конференции (Ставрополь, 28-29 сентября 2015 г.). Ставрополь: СКФУ, 2016. С. 164-170.

28. Крючков И. В. Экономические связи Австро-Венгрии с Персией в конце XIX - начале XX вв. (по материалам российских дипломатов) // Историко-культурное наследие Великого шелкового пути и продвижение туристских дестинаций на Северном Кавказе: материалы III Международной научно-практической конференции (Ставрополь, 5-7 октября 2017 г.). Ставрополь: СКФУ, 2017. Р. 46-49.

29. Кудрявцев А. А. Великая Китайская стена и дербентский фортификационный комплекс в истории мировых торговых путей Евразии // Историко-культурное наследие Великого шелкового пути и продвижение туристских дестинаций на Северном Кавказе: материалы III Международной научно-практической конференции (Ставрополь, 5-7 октября 2017 г.). Ставрополь: СКФУ, 2017.С. 49-53. 
30. Кудрявцев А. А. Дербент в истории Великого шелкового пути в античный период // Историко-культурное наследие Великого шелкового пути и продвижение туристских дестинаций на Северном Кавказе: материалы Международной научно-практической конференции (Ставрополь, 28-29 сентября 2015 г.). Ставрополь: СКФУ, 2016. С. 30-37.

31. Кудрявцев Е. А. Китайский импорт из раскопок средневекового Дербента (по материалам раскопок 19701995 гг.) // Историко-культурное наследие Великого шелкового пути и продвижение туристских дестинаций на Северном Кавказе: материалы III Международной научно-практической конференции (Ставрополь, 5-7 октября 2017 г.) Ставрополь: СКФУ, 2017. С. 53-56

32. Лесков А. М., Беглова Е. А., Ксенофонтова И. В., Эрлих В. Р. Меоты Закубанья в середине VI - начале III века до н.э. Некрополи у аула Уляп: погребальные комплексы. М.: Ин-т археологии, 2005. 192 с.

33. Ли Джи Ын. Китайский импорт в памятниках Юга России (І в. до н.э. - ІІІ в. н. э.): автореф. дисс. канд. ист. наук. Ставрополь: СГУ, 2010. 33 с.

34. Махортих С. В., Скорий С. А. Мечі та кинджали скіфського часу без навершів //Археологія. 1986. №56. С. 72-78.

35. Международное сотрудничество археологов на великих торговых и культурных путях древности и средневековья. Тезисы докладов международной конференции. Кисловодск: [б.и.], 1994. 75 с.

36. Мелконян А. А. Западная Армения в сфере экономических отношений Восток-Запад // Историко-культурное наследие Великого шелкового пути и продвижение туристских дестинаций на Северном Кавказе: материалы III Международной научно-практической конференции (Ставрополь, 5-7 октября 2017 г.). Ставрополь: СКФУ, 2017. С. 64-68.

37. Муханов В. М. Покоритель Кавказа князь А. И. Барятинский. М.: ЗАО Центрполиграф, 2007. 428 с

38. Пикалов Д. В. Следы зороастризма и манихейства на торговых путях северного Кавказа // Историко-культурное наследие Великого шелкового пути и продвижение туристских дестинаций на Северном Кавказе: материалы III Международной научно-практической конференции (Ставрополь, 5-7 октября 2017 г.). Ставрополь: СКФУ, 2017. С.110-114.

39. По предположениям наместника кавказского князя А. И. Барятинского об учреждении Общества восстановления православия на Кавказа // Кавказ и Российская империя: проекты, иллюзии и реальность. Начало XIX - начала XX вв. / сост. Я. А. Гордин, В. В. Лапин, Г. Г. Лисцина, Б. П. Миловидов. СПб: Издательство журнала «Звезда», 2005 C. $409-432$

40. Попова Л. Ф. Отражение торговых связей средней Азии и Казахстана (XIX в.) в коллекциях Российского этнографического музея // Историко-культурное наследие Великого шелкового пути и продвижение туристских дестинаций на Северном Кавказе: материалы III Международной научно-практической конференции (Ставрополь, 5-7 октября 2017 г.) Ставрополь: СКФУ, 2017. С. 76-79

41. Прокопенко Ю. А. О номенклатуре товаров, транспортировавшихся китайскими купцами в города Византии по северной трассе Великого шелкового пути (по материалам могильников Центрального Предкавказья) // Историко-культурное наследие Великого шелкового пути и продвижение туристских дестинаций на Северном Кавказе: материалы III Международной научно-практической конференции (Ставрополь, 5-7 октября 2017 г.). Ставрополь: СКФУ, 2017. C. $80-82$

42. Прокопенко Ю. А. Цикличность функционирования транзитных путей на Северном Кавказе в V - XI вв. // Историко-культурное наследие Великого шелкового пути и продвижение туристских дестинаций на Северном Кавказе: материалы Международной научно-практической конференции (Ставрополь, 28-29 сентября 2015 г.). Ставрополь: СКФУ, 2016. С. 70-80.

43. Ривкин К. Холодное оружие Кавказа. Определитель // История оружия. 2012. №7. С. 57-58

44. Садченко В. Н. Экономический потенциал Великого шелкового пути и перспективы ЕАЭС // Историко-культурное наследие Великого шелкового пути и продвижение туристских дестинаций на Северном Кавказе: материалы III Международной научно-практической конференции (Ставрополь, 5-7 октября 2017 г.). Ставрополь: СКФУ, 2017. С. 82-86.

45. Северный Кавказ в составе Российской империи. М.: Новое литературное обозрение, 2007. 460 c

46. Скаков А. Ю. Транскавказские перевальные маршруты в древности и перспективы их восстановления в начале XXI в. // Историко-культурное наследие Великого шелкового пути и продвижение туристских дестинаций на Северном Кавказе: материалы Международной научно-практической конференции (Ставрополь, 28-29 сентября 2015 г.). Ставрополь: СКФУ, 2016. Р. 57-65

47. Судавцов Н. Д. Роль А. Ф. Реброва в развитии шелководства на северном кавказе в первой половине XIX в. // Историко-культурное наследие Великого шелкового пути и продвижение туристских дестинаций на Северном Кавказе: материалы III Международной научно-практической конференции (Ставрополь, 5-7 октября 2017 г.). Ставрополь СКФУ, 2017. С. 86-88.

48. Судавцов Н. Д. Традиции шелководства на Северном Кавказе // Историко-культурное наследие Великого шелкового пути и продвижение туристских дестинаций на Северном Кавказе: материалы Международной научно-практической конференции (Ставрополь, 28-29 сентября 2015 г.). Ставрополь: СКФУ, 2016. С.170-174.

49. Сулейманова С. А. Кавказские маршруты в трансконтинентальной сети древних путей // Историко-культурное наследие Великого шелкового пути и продвижение туристских дестинаций на Северном Кавказе: материалы Международной научно-практической конференции (Ставрополь 28-29 сентября 2015 г.). Ставрополь: СКФУ, 2016. С. 45-56.

50. Туаллагов А. А. К открытию северного маршрута Великого шелкового пути // Историко-культурное наследие Великого шелкового пути и продвижение туристских дестинаций на Северном Кавказе: материалы Международной научно-практической конференции (Ставрополь, 28-29 сентября 2015 г.). Ставрополь: СКФУ, 2016. С. 65-70.

51. Цуциев А. А. Восточные предметы в аланских памятниках горной Осетии // Историко-культурное наследие Великого шелкового пути и продвижение туристских дестинаций на Северном Кавказе: материалы III Международной научно-практической конференции (Ставрополь, 5-7 октября 2017 г.). Ставрополь: СКФУ, 2017. С. 137-140.

52. Элита в истории древних и средневековых народов Евразии. Коллективная монография. Барнаул: Изд. АГУ, 2015. $330 \mathrm{c}$

53. Эрлих В. Р. Меотские мечи из Закубанья // Древности Северного Кавказа и Причерноморья. М.: Государственный музей искусства народов Востока, 1991. С. 77-99. 
54. Csicsmann L. The fault lines in the Middle East after the Military Defeat of ISIS. (Линии разлома на Ближнем Востоке после военного поражения ИЗИС) // Историко-культурное наследие Великого шелкового пути и продвижение туристских дестинаций на Северном Кавказе: материалы III Международной научно-практической конференции (Ставрополь, 5-7 октября 2017 г.). Ставрополь: СКФУ, 2017. Р. 93-96.

55. Picchelauri K. Waffen der Bronzezeit aus Ost-Georgien // Archäologie in Eurasien. Band 4. Berlin, 1997. Taf. 12, 17.

\section{References}

1. Babenko V. A. Torgovye puti Tsentral'nogo Predkavkaz'ya v epokhu Zolotoi Ordy (Trade routes of the Central Ciscaucasia in the era of the Golden Horde) // Istoriko-kul'turnoe nasledie Velikogo shelkovogo puti i prodvizhenie turistskikh destinatsii na Severnom Kavkaze: materialy Mezhdunarodnoi nauchno-prakticheskoi konferentsii (Stavropol', September, 28-29, 2015) Stavropol': NSFU publ., 2016. P. 87-91. (In Russian)

2. Batchaev V. M. Balkariya $\vee X V$ - nachale XIX V. (Balkaria in the XV - the beginning of XIX century). Moscow: Institute Caucasian People publ., 2006. 239 p. (In Russian)

3. Belikova T. V. Petr I i ideya pereneseniya vostochnoi torgovli shelkom na territoriyu Rossii (Peter I and the idea of transferring eastern silk trade to Russia) // Istoriko-kul'turnoe nasledie Velikogo shelkovogo puti i prodvizhenie turistskikh destinatsii na Severnom Kavkaze: materialy III Mezhdunarodnoi nauchno-prakticheskoi konferentsii (Stavropol', September, 28-29, 2015). Stavropol': NSFU publ., 2016. P. 10-13. (In Russian)

4. Burkov S. B., Mal'sagov A. I. Novye nakhodki kitaiskikh bronz iz Ingushetii (New findings of Chinese bronzes from Ingushetia) // Istoriko-kul'turnoe nasledie Velikogo shelkovogo puti i prodvizhenie turistskikh destinatsii na Severnom Kavkaze materialy Mezhdunarodnoi nauchno-prakticheskoi konferentsii (Stavropol', September 28-29, 2015). Stavropol': NSFU publ., 2016. (In Russian)

5. Vardumyan G. Armeniya na Velikom shelkovom puti (Armenia on the Great Silk Road) // Istoriko-kul'turnoe nasledie Velikogo shelkovogo puti i prodvizhenie turistskikh destinatsii na Severnom Kavkaze: materialy III Mezhdunarodnoi nauchnoprakticheskoi konferentsii (Stavropol', October, 5-7, 2017). Stavropol': NSFU publ., 2017. P.13-17. (In Russian)

6. Vasil'ev L. S. Istoriya Vostoka (Oriental History). In 2 Vols. Vol.1. Moscow: Higher School publ., 1994. 495 p. (In Russian)

7. Velichko L. N. Evolyutsiya programmy evropeiskoi politiki sosedstva na Yuzhnom Kavkaze (Evolution of the European Neighborhood Policy Program in the South Caucasus) // Istoriko-kul'turnoe nasledie Velikogo shelkovogo puti i prodvizhenie turistskikh destinatsii na Severnom Kavkaze: materialy III Mezhdunarodnoi nauchno-prakticheskoi konferentsii (Stavropol' October, 5-7, 2017). Stavropol': NSFU publ., 2017. P. 21-25. (In Russian)

8. Vestnik Shelkovogo puti. Arkheologicheskie istochniki (Bulletin of the Silk Road. Archaeological sources). Issue. 1. Moscow: Silk road publ., 1993. 340 s. (In Russian)

9. Vinogradov V. B., Dudarev S. L., Narozhnyi E. I. Osnovnye etapy vsemirnoi istorii. Metodicheskii material (Main stages of World History. Methodical materials) // Vostok. Aziatskie obshchestva: istoriya i sovremennost'. 1995. No. 5. P. 126-135. (In Russian)

10. Gagloev R. Kh. Torgovo-ekonomicheskie vzaimootnosheniya naseleniya Yuzhnoi Osetii $s$ antichnym mirom $v$ Sarmatsko-Alanskii period (Trade and economic relationships of South Ossetia with antique in Sarmatian-Alan period) /I Istoriko-kul'turnoe nasledie Velikogo shelkovogo puti i prodvizhenie turistskikh destinatsii na Severnom Kavkaze: materialy Mezhdunarodnoi nauchno-prakticheskoi konferentsii (Stavropol', September 28-29, 2015). Stavropol': NSFU publ., 2016. P. 102-108. (In Russian)

11. Garunova N. N. Indiiskie kuptsy v sostave astrakhanskogo i kizlyarskogo kupechestva v XVII - seredine XVIII vV (Indian merchants into Astrakhan and Kizlyarin XVII - the middle XVIII) // Istoriko-kul'turnoe nasledie Velikogo shelkovogo puti i prodvizhenie turistskikh destinatsii na Severnom Kavkaze: materialy Mezhdunarodnoi nauchno-prakticheskoi konferentsii (Stavropol', September, 28-29, 2015). Stavropol': NSFU publ., 2016. P. 161-164. (In Russian)

12. Dmitriev V. A. Traditsionnaya gorskaya ekonomika narodov Severnogo Kavkaza $v$ kontekste naslediya Velikogo shelkovogo puti (Traditional economy of mountain peoples of the North Caucasus in the context of the Great Silk Road heritage) // Istoriko-kul'turnoe nasledie Velikogo shelkovogo puti i prodvizhenie turistskikh destinatsii na Severnom Kavkaze materialy III Mezhdunarodnoi nauchno-prakticheskoi konferentsii (Stavropol', October, 5-7, 2017 ). Stavropol': NSFU publ., 2017. P. 28-32. (In Russian)

13. Dudarev D. S., Dudarev S. L. Severnyi Kavkaz glazami predstavitelei rossiiskogo obshchestva pervoi poloviny serediny XIX veka (The North Caucasus through the eyes of representatives of Russian society in the first half - mid-XIX-th century). Armavir; Stavropol': Dizain-studiya B, 2017. 402 p. (In Russian)

14. Dudarev S. L. Vzaimootnosheniya plemen Severnogo Kavkaza s kochevnikami Yugo-Vostochnoi Evropy v predskifskuyu epokhu (Relations between the tribes of the North Caucasus and the nomads of Southeast Europe in the pre-Scythian era). Armavir: Armavirskoe poligraf-predpriyatie publ., 1999. 400 p. (In Russian)

15. Dudarev S. L. O spetsifike islamizatsii Severo-Zapadnogo Kavkaza v 1830 - nachale 1860-kh gg. (On the specifics of Islamization of the North-West Caucasus in 1830 - early 1860s.) // Materialy III Mezhdunarodnogo foruma istorikovkavkazovedov «Russko-kavkazskie otnosheniya: ot pervykh kontaktov do sovremennogo edinstva» (November 17, 2015 Rostov-on-Don). Rostov-on-Don: Foundation for Science and Education publ., 2015. P.145-149. (In Russian)

16. Dumikyan A. Armyanskii kul'turno-ekonomicheskii faktor $v$ osveshchenii frantsuzskoi istoriografii $v$ kontekste shelkovogo puti (Armenian cultural and economic factor in the coverage of French historiography in the context of the Silk Road) // Istoriko-kul'turnoe nasledie Velikogo shelkovogo puti i prodvizhenie turistskikh destinatsii na Severnom Kavkaze materialy Mezhdunarodnoi nauchno-prakticheskoi konferentsii (Stavropol', September, 28-29, 2015). Stavropol': NSFU publ. 2016. P. 114-118. (In Russian)

17. Ermolenko L. P. Problemy i perspektivy razvitiya turistskoi otrasli na Severnom Kavkaze (Problems and prospects for the development of the tourism industry in the North Caucasus) // Istoriko-kul'turnoe nasledie Velikogo shelkovogo puti i prodvizhenie turistskikh destinatsii na Severnom Kavkaze: materialy III Mezhdunarodnoi nauchno-prakticheskoi konferentsii (Stavropol', October, 5-7, 2017). Stavropol': NSFU publ., 2017. P. 32-34. (In Russian) 
18. Istoriko-kul'turnoe nasledie Velikogo shelkovogo puti i prodvizhenie turistskikh destinatsii na Severnom Kavkaze: materialy III Mezhdunarodnoi nauchno-prakticheskoi konferentsii (The historical and cultural heritage of the Great Silk Road and the promotion of tourist destinations in the North Caucasus: proceedings of the III International Scientific and Practical Conference) (Stavropol', October, 5-7, 2017). Stavropol': NSFU publ., 2017. P. 32-34. (In Russian)

19. Istoriya Vostoka. (Oriental History) in 6 Vols. Vol.1. East in ancient time. Moscow: Vost.lit. publ., 1997. 688 p. (In Russian)

20. Kaitan Sh. G. Rannesrednevekovye kreposti Abkhazii na Velikom shelkovom puti (problemy vyyavleniya, ucheta i sokhraneniya) (Early medieval fortresses of Abkhazia on the Great Silk Road (problems of identification, accounting and conservation) // Istoriko-kul'turnoe nasledie Velikogo shelkovogo puti i prodvizhenie turistskikh destinatsii na Severnom Kavkaze: materialy Mezhdunarodnoi nauchno-prakticheskoi konferentsii (Stavropol', September, 28-29, 2015). Stavropol': NSFU publ., 2016. P. 42-45. (In Russian)

21. Kolesnikova M. E. Severokavkazskaya trassa Velikogo shelkovogo puti: k istoriografii voprosa (The North Caucasus Highway of the Great Silk Road: On the Historiography of the Question) // Istoriko-kul'turnoe nasledie Velikogo shelkovogo puti i prodvizhenie turistskikh destinatsii na Severnom Kavkaze: materialy Mezhdunarodnoi nauchno-prakticheskoi konferentsii (Stavropol', September, 28-29, 2015). Stavropol': NSFU publ., 2016. P. 118-122. (In Russian)

22. Kolesnikova M. E. Sledy Velikogo shelkovogo puti na Severnom Kavkaze: gorodishche Madzhary $v$ istoricheskikh sochineniyakh XVIII veka (The Footprints of the Silk Road in the North Caucasus: ancient settlement Madjars in historical works in XVIII) // Istoriko-kul'turnoe nasledie Velikogo shelkovogo puti i prodvizhenie turistskikh destinatsii na Severnom Kavkaze: materialy III Mezhdunarodnoi nauchno-prakticheskoi konferentsii (Stavropol', October, 5-7, 2017). Stavropol': NSFU publ., 2017. P. 35-38. (In Russian)

23. Kolontari A. Istoriko-kul'turnoe nasledie Yugo-Zapadnoi Vengrii i perspektivy razvitiya turizma v regione (The historical and cultural heritage of South-West Hungary and the prospects for tourism development in the region) // Istoriko-kul'turnoe nasledie Velikogo shelkovogo puti i prodvizhenie turistskikh destinatsii na Severnom Kavkaze: materialy III Mezhdunarodnoi nauchno-prakticheskoi konferentsii (Stavropol', October, 5-7, 2017). Stavropol': NSFU publ., 2017. P. 38-41. (In Russian)

24. Kol'tsov P. M. Kol'tsova K. P. Velikii shelkovyi put' na territorii Kalmykii (The Great Silk Road in Kalmykia) // Istorikokul'turnoe nasledie Velikogo shelkovogo puti i prodvizhenie turistskikh destinatsii na Severnom Kavkaze: materialy III Mezhdunarodnoi nauchno-prakticheskoi konferentsii (Stavropol', October, 5-7, 2017). Stavropol': NSFU publ., 2017. P. 4244. (In Russian)

25. Kopylov V. P. Rol' urbanisticheskikh tsentrov Nizhnedonskogo kul'turno-istoricheskogo raiona $v$ tranzitnoi torgovle Vostoka i Zapada (pervaya polovinaVI - pervaya polovinalll vv. do n.e.) (The role of urban centers of the Nizhny Don cultural and historical region in the transit trade of the East and West (first half of the VI - first half of the VIII-th centuries BC) II Istoriko-kul'turnoe nasledie Velikogo shelkovogo puti i prodvizhenie turistskikh destinatsii na Severnom Kavkaze: materialy Mezhdunarodnoi nauchno-prakticheskoi konferentsii (Stavropol', September, 28-29, 2015). Stavropol': NSFU publ., 2016. P. 80-87. (In Russian)

26. Korobkina I. A. Novyi shelkovyi put': realizatsiya kontseptsii kitaiskogo proekta "Odin poyas i odin put'» (The New Silk Road: the implementation of the concept of the Chinese project "One Belt and One Way") // Istoriko-kul'turnoe nasledie Velikogo shelkovogo puti i prodvizhenie turistskikh destinatsii na Severnom Kavkaze: materialy III Mezhdunarodnoi nauchnoprakticheskoi konferentsii (Stavropol', October, 5-7, 2017). Stavropol': NSFU publ., 2017. P. 44-46. (In Russian)

27. Kryuchkov I. V. Kavkaz v mirovoi ekonomicheskoi sisteme XIX - nachala XX vekov: prodolzhenie traditsii Velikogo shelkovogo puti (The Caucasus in the global economic system of the 19th and early 20th centuries; the continuation of the traditions of the Great Silk Road) // Istoriko-kul'turnoe nasledie Velikogo shelkovogo puti i prodvizhenie turistskikh destinatsii na Severnom Kavkaze: materialy Mezhdunarodnoi nauchno-prakticheskoi konferentsii (Stavropol', September, 28-29, 2015). Stavropol': NSFU publ., 2016. P. 164-170. (In Russian)

28. Kryuchkov I. V. Ekonomicheskie svyazi Avstro-Vengrii s Persiei v kontse XIX - nachale XX vv. (po materialam rossiiskikh diplomatov) (Economic relations of Austria-Hungary with Persia in the late twentieth - early twentieth centuries (based on materials of Russian diplomats) // Istoriko-kul'turnoe nasledie Velikogo shelkovogo puti i prodvizhenie turistskikh destinatsii na Severnom Kavkaze: materialy III Mezhdunarodnoi nauchno-prakticheskoi konferentsii (Stavropol', October, 5-7, 2017). Stavropol': NSFU publ., 2017. P. 46-49. (In Russian)

29. Kudryavtsev A. A. Velikaya Kitaiskaya stena i derbentskii fortifikatsionnyi kompleks $v$ istorii mirovykh torgovykh putei Evrazii (The Great Wall of China and Derbent Fortification Complex in the History of Eurasia World Trade Routes) /I Istoriko-kul'turnoe nasledie Velikogo shelkovogo puti i prodvizhenie turistskikh destinatsii na Severnom Kavkaze: materialy III Mezhdunarodnoi nauchno-prakticheskoi konferentsii (Stavropol', October, 5-7, 2017). Stavropol': NSFU publ., 2017. P. 4953. (In Russian)

30. Kudryavtsev A. A. Derbent $v$ istorii Velikogo shelkovogo puti v antichnyi period (Derbent in the history of the Great Silk Road in the ancient period) // Istoriko-kul'turnoe nasledie Velikogo shelkovogo puti i prodvizhenie turistskikh destinatsii na Severnom Kavkaze: materialy Mezhdunarodnoi nauchno-prakticheskoi konferentsii (Stavropol', September, 28-29, 2015). Stavropol': NSFU publ., 2016. P. 30-37. (In Russian)

31. Kudryavtsev E. A. Kitaiskii import iz raskopok srednevekovogo Derbenta (po materialam raskopok 1970-1995 gg.) (Chinese imports from excavations of medieval Derbent (based on excavations from 1970-1995) // Istoriko-kul'turnoe nasledie Velikogo shelkovogo puti i prodvizhenie turistskikh destinatsii na Severnom Kavkaze: materialy III Mezhdunarodnoi nauchnoprakticheskoi konferentsii (Stavropol', October, 5-7, 2017). Stavropol': NSFU publ., 2017. P. 53-56. (In Russian)

32. Leskov A. M., Beglova E. A., Ksenofontova I. V., Erlikh V. R. Meoty Zakuban'ya v seredine VI - nachale III veka do n.e. Nekropoli u aula Ulyap: pogrebal'nye kompleksy (Meots of the Trans-Kuban in the middle of the VI-beginning of the III century BC Necropolises at Ulyap aul: funerary complexes). Moscow: Institute of Archeology of RAS publ., 2005. 192 p. (In Russian)

33. Li Dzhi Yn. Kitaiskii import v pamyatnikakh Yuga Rossii (I v. do n.e. - III v. n. e.) (Chinese imports in the monuments of the South of Russia (I century BC - III century AD): abstract of thesis. Stavropol': SSU publ., 2010. 33 p. (In Russian) 
34. Makhortikh S. V., Skorii S. A. Mechi ta kindzhali skifs'kogo chasu bez avershiv (Swords and canals of Scythian hour without finishes) //Arkheologiya. 1986. No. 56. P. 72-78. (In Russian)

35. Mezhdunarodnoe sotrudnichestvo arkheologov na velikikh torgovykh i kul'turnykh putyakh drevnosti i srednevekov'ya Tezisy dokladov mezhdunarodnoi konferentsii (International cooperation of archaeologists on the great trade and cultural routes of antiquity and the Middle Ages). Abstracts of reports of the international conference. Kislovodsk: [b.i.], 1994. 75 p (In Russian)

36. Melkonyan A. A. Zapadnaya Armeniya v sfere ekonomicheskikh otnoshenii Vostok-Zapad (Western Armenia in the fie/d of economic relations East-West) // Istoriko-kul'turnoe nasledie Velikogo shelkovogo puti i prodvizhenie turistskikh destinatsii na Severnom Kavkaze: materialy III Mezhdunarodnoi nauchno-prakticheskoi konferentsii (Stavropol', October, 5-7, 2017) Stavropol': NSFU publ., 2017. P. 64-68. (In Russian)

37. Mukhanov V. M. Pokoritel' Kavkaza knyaz' A. I. Baryatinskii (The Conqueror of the Caucasus Prince A.I. Baryatinsky). Moscow: ZAO Tsentrpoligraf publ., 2007. 428 p. (In Russian)

38.Pikalov D. V. Sledy zoroastrizma i manikheistva na torgovykh putyakh severnogo Kavkaza (Traces of Zoroastrianism and Manichaeism on the trade routes of the North Caucasus) // Istoriko-kul'turnoe nasledie Velikogo shelkovogo puti prodvizhenie turistskikh destinatsii na Severnom Kavkaze: materialy III Mezhdunarodnoi nauchno-prakticheskoi konferentsii (Stavropol', October, 5-7, 2017). Stavropol': NSFU publ., 2017. P. 110-114. (In Russian)

39. Po predpolozheniyam namestnika kavkazskogo knyazya A. I. Baryatinskogo ob uchrezhdenii Obshchestva vosstanovleniya pravoslaviya na Kavkaza (According to the assumptions of the governor of the Caucasus prince A.I. Baryatinsky on the establishment of the Society for the Restoration of Orthodoxy in the Caucasus) // Kavkaz i Rossiiskaya imperiya: proekty, illyuzii i real'nost'. Nachalo XIX - nachala XX vv. St.Petersburg: Publishisng house of magazin "Zvezda», 2005. P. 409-432. (In Russian)

40. Popova L. F. Otrazhenie torgovykh svyazei srednei Azii i Kazakhstana (XIX v.) $\vee$ kollektsiyakh Rossiiskogo etnograficheskogo muzeya (Reflection of trade relations of Central Asia and Kazakhstan ( $X X$ century) in the collections of the Russian Ethnographic Museum) // Istoriko-kul'turnoe nasledie Velikogo shelkovogo puti i prodvizhenie turistskikh destinatsii na Severnom Kavkaze: materialy III Mezhdunarodnoi nauchno-prakticheskoi konferentsii (Stavropol', October, 5-7, 2017) Stavropol': NSFU publ., 2017. P. 76-79. (In Russian)

41. Prokopenko Yu. A. O nomenklature tovarov, transportirovavshikhsya kitaiskimi kuptsami $v$ goroda Vizantii po severnoi trasse Velikogo shelkovogo puti (po materialam mogil'nikov Tsentral'nogo Predkavkaz'ya) (On the nomenclature of goods transported by Chinese merchants to the cities of Byzantium along the northern route of the Great Silk Road (based on materials from the burial grounds of the Central Ciscaucasia) // Istoriko-kul'turnoe nasledie Velikogo shelkovogo puti i prodvizhenie turistskikh destinatsii na Severnom Kavkaze: materialy III Mezhdunarodnoi nauchno-prakticheskoi konferentsii (Stavropol', October, 5-7, 2017). Stavropol': NSFU publ., 2017. P. 80-82. (In Russian)

42. Prokopenko Yu. A. Tsiklichnost' funktsionirovaniya tranzitnykh putei na Severnom Kavkaze v V-XI vv. (Cycling of the functioning of transit routes in the North Caucasus in V-VI) // Istoriko-kul'turnoe nasledie Velikogo shelkovogo puti i prodvizhenie turistskikh destinatsii na Severnom Kavkaze: materialy Mezhdunarodnoi nauchno-prakticheskoi konferentsii (Stavropol', September, 28-29, 2015). Stavropol': NSFU publ., 2016. P. 70-80. (In Russian)

43. Rivkin K. Kholodnoe oruzhie Kavkaza. Opredelitel' (Cold weapons of the Caucasus, Identification Guide) // Istoriya oruzhiya. 2012. No.7. P. 57-58. (In Russian)

44. Sadchenko V. N. Ekonomicheskii potentsial Velikogo shelkovogo puti i perspektivy EAES (Economic potential of the Great Silk Road and the prospects of the EAEU) // Istoriko-kul'turnoe nasledie Velikogo shelkovogo puti i prodvizhenie turistskikh destinatsii na Severnom Kavkaze: materialy III Mezhdunarodnoi nauchno-prakticheskoi konferentsii (Stavropol' October, 5-7, 2017). Stavropol': NSFU publ., 2017. P. 82-86. (In Russian)

45. Severnyi Kavkaz $\vee$ sostave Rossiiskoi imperii (North Caucasus as a part of the Russian Empire). Moscow: Novoe literaturnoe obozrenie, 2007. $460 \mathrm{p}$.

46. Skakov A. Yu. Transkavkazskie pereval'nye marshruty v drevnosti i perspektivy ikh vosstanovleniya v nachale XXI v (Transcaucasian transit routes in antiquity and the prospects for their restoration at the beginning of XXI) // Istoriko-kul'turnoe nasledie Velikogo shelkovogo puti i prodvizhenie turistskikh destinatsii na Severnom Kavkaze: materialy Mezhdunarodnoi nauchno-prakticheskoi konferentsii (Stavropol', September, 28-29, 2015). Stavropol': NSFU publ., 2016. P. 57-65. (In Russian)

47. Sudavtsov N. D. Rol' A.F. Rebrova v razvitii shelkovodstva na severnom kavkaze v pervoi polovine XIX v. (The role of A.F. Rebrov in the development of sericulture in the North Caucasus in the first half of the XIX century) // Istoriko-kul'turnoe nasledie Velikogo shelkovogo puti i prodvizhenie turistskikh destinatsii na Severnom Kavkaze: materialy III Mezhdunarodnoi nauchno-prakticheskoi (Stavropol', October, 5-7, 2017). Stavropol': NSFU publ., 2017. P. 86-88. (In Russian)

48. Sudavtsov N. D. Traditsii shelkovodstva na Severnom Kavkaze (Sericulture traditions in the North Caucasus) // Istoriko-kul'turnoe nasledie Velikogo shelkovogo puti i prodvizhenie turistskikh destinatsii na Severnom Kavkaze: materialy Mezhdunarodnoi nauchno-prakticheskoi konferentsii (Stavropol', September, 28-29, 2015). Stavropol': NSFU publ., 2016 P. 170-174. (In Russian)

49. Suleimanova S. A. Kavkazskie marshruty $v$ transkontinental'noi seti drevnikh putei (Caucasian routes in the transcontinental network of ancient ways) // Istoriko-kul'turnoe nasledie Velikogo shelkovogo puti i prodvizhenie turistskikh destinatsii na Severnom Kavkaze: materialy Mezhdunarodnoi nauchno-prakticheskoi konferentsii (Stavropol', September, 28-29, 2015). Stavropol': NSFU publ., 2016. P. 45-56. (In Russian)

50. Tuallagov A. A. K otkrytiyu severnogo marshruta Velikogo shelkovogo puti (On the opening of the northern route of the Great Silk Road) // Istoriko-kul'turnoe nasledie Velikogo shelkovogo puti i prodvizhenie turistskikh destinatsii na Severnom Kavkaze: materialy Mezhdunarodnoi nauchno-prakticheskoi konferentsii (Stavropol', September, 28-29, 2015). P. 65-70. (In Russian) 
51. Tsutsiev A. A. Vostochnye predmety $v$ alanskikh pamyatnikakh gornoi Osetii (Oriental items in Alan monuments of mountain Ossetia) // Istoriko-kul'turnoe nasledie Velikogo shelkovogo puti i prodvizhenie turistskikh destinatsii na Severnom Kavkaze: materialy III Mezhdunarodnoi nauchno-prakticheskoi konferentsii (Stavropol', October, 5-7, 2017). Stavropol': NSFU publ., 2017. P. 137-140. (In Russian)

52. Elita v istorii drevnikh i srednevekovykh narodov Evrazii (Elite in the history of ancient and medieval peoples of Eurasia). Barnaul: ASU publ., 2015. 330 p. (In Russian)

53. Erlikh V. R. Meotskie mechi iz Zakuban'ya (Meotian Swords of the Zakubanie) // Drevnosti Severnogo Kavkaza i Prichernomor'ya. Moscow: Gosudarstvennyi muzei iskusstva narodov Vostoka, 1991. P. 77-99. (In Russian)

54. Csicsmann L. The fault lines in the Middle East after the Military Defeat of ISIS // Istoriko-kul'turnoe nasledie Velikogo shelkovogo puti i prodvizhenie turistskikh destinatsii na Severnom Kavkaze: materialy III Mezhdunarodnoi nauchnoprakticheskoi konferentsii (Stavropol' 5-7 oktyabrya 2017 g.). Stavropol': SKFU, 2017. P. 93-96.

55. Picchelauri K. Waffen der Bronzezeit aus Ost-Georgien // Archāologie in Eurasien. Band 4. Berlin, 1997. Taf. 12, 17.

\section{Сведения об авторе}

Дударев Сергей Леонидович - доктор исторических наук, профессор кафедры всеобщей и отечественной истории Армавирского государственного педагогического университета (Армавир) / dudarev51@mail.ru

\section{Information about the author}

Dudarev Sergei - Doctor of History, Professor, Chair of General and Russian History, Armavir State Pedagogical University (Armavir) / dudarev51@mail.ru 